The Agriculturists 11(2): 96- 103(2013)ＩSSN 2304-7321 (Online), ISSN 1729-5211 (Print)

\title{
Efficacy of Some Rhizosphere Microorganisms in Controlling Fusarium Wilt of Tomato (Lycopersicon esculentum)
}

\author{
A. M. Sarker, N. Sultana*, M. R. Islam, M. Rashid and Z. R. Bhuian \\ Department of Plant Pathology, Sher-e-Bangla Agricultural University, Dhaka, Bangladesh \\ *Corresponding author and Email: nazneensau@yahoo.com
}

Received: 04 September $2013 \quad$ Accepted: 06 December 2013

\begin{abstract}
An experiment was conducted at the Disease Diagnostic Laboratory and Net House of Plant Pathology Department, Sher-e-Bangla Agricultural University, Dhaka during July 2011 to June 2012 to investigate the efficacy of some antagonistic rhizosphere microorganisms against Fusarium oxysporum f. sp. lycopersici causing Fusarium wilt of tomato. Probable 20 antagonistic bacterial isolates and one antagonistic fungal isolate (Trichoderma harzianum) from rhizosphere soil were screened out against F. oxysporum f. sp. lycopersici. Out of 20 bacterial isolates, only four (Iso-1, Iso-2, Iso-3 and Iso-4) were found effective in dual culture method. Out of all antagonists, Trichoderma harzianum produced the highest inhibition zone $(75.75 \%)$, while the lowest inhibition zone $(28.39 \%)$ was produced by Iso2. In blotter method, the highest prevalence of Fusarium oxysporum was observed in control (11.25\%), while the lowest was in Iso-1 $(0.58 \%)$ treated seeds.
\end{abstract}

Keywords: Rhizosphere microorganisms, control, fusarium wilt, tomato

\section{Introduction}

Tomato (Lycopersicon esculentum) is one of the most popular and important commercial vegetable grown throughout the world. Bangladesh produced 324 thousand metric tons of tomato from 104 thousand hectares of land (BBS, 2011). Many diseases and disorders can affect tomatoes during the growing season. Fusarium wilt is one of the serious diseases of tomato throughout the world, especially in Bangladesh. This disease is caused by Fusarium oxysporum f. sp. lycopersici leading to serious economic losses (Snyder and Hansen, 1940).

There may be 60 to $70 \%$ yield loss due to this disease (Kirankumar et al., 2008). The excessive misuse of a wide range of fungicides has resulted this to be harmful to the environment and increased the resistant pathogen populations (Ogzonen et al., 2001). F. oxysporum f. sp. lycopersici becomes resistant to those chemical fungicides. For this reason, alternative methods to control the disease have to study with emphasis on biological control using fungi or bacteria to reduce fungicide application and decrease cost of production. As this pathogen is soil borne, biological control could be a suitable measure against it. It is attractive in an environmental and economic sense offering durable, safe and cost effective means to control the diseases as an alternative to chemicals (Merriman and Russell, 1990). Moreover biological control is less disruptive to ecosystem than that of chemical pesticides (Cook and Baker, 1983). 
Despite economic importance, sufficient information has not been generated so far about the management of this worldwide prevalent disease. Therefore, the study was conducted to search for suitable antagonistic rhizosphere microorganisms against it.

\section{Materials and Methods}

For studying the antagonistic ability of Trichoderma herzianum and some bacterial antagonists against Fusarium oxysporum f. sp. lycopersici the antagonistic fungus as well as the bacterial isolates was isolated from rhizosphere soil. Bacteria were isolated by dilution plate method of Goszczynska and Serfontein (1998) and colony was purified on NA plates. Similarly, T.herzianum was isolated and purified on PDA plates following a standard method (Ashrafuzzaman, 1976). For the study F. oxysporum f. sp. lycopersici was isolated from seeds of tomato variety BARI tomato-2, collected from Bangladesh Agricultural Research Institute, Gazipur. Prevalence of other fungi on the collected seeds was also studied by blotter method (ISTA, 1996). The antagonistic ability of the bacterial isolates was studied In-vitro following a dual culture method described by Azadeh et al. (2010). A $5 \mathrm{~mm}$ plug of the fungus $F$. oxysporum $\mathrm{f}$. sp. lycopersici at the centre of a petri-dish containing $25 \mathrm{ml}$ PDA, then the test bacterial isolate was streaked $3 \mathrm{~cm}$ away from the fungal plug both sides towards the edge of the plate by a loop loaded with $48 \mathrm{hr}$ old bacterial culture. A control was maintained without streaking of bacteria in the plate. The test plates were then incubated at $28^{\circ} \mathrm{C}$ for 7 days. Similarly, for testing the antagonism of $T$. herzianum the dual culture technique described by Sundar et al. (1995). Discs of 5mm diameter of both the test fungi were cut with a sharp cork borer from the growing edge of the culture plate. A $5 \mathrm{~mm}$ block (7 days old) of $T$. herzianum was placed to PDA plate on one side and another block of $F$. oxysporum f. sp. lycopersici was placed at the other side. A plate only with the disc of $F$. oxysporum f. sp. lycopersici at the centre was used as control. The test plates were then incubated at room temperature $\left(25 \pm 2^{0} \mathrm{C}\right)$ until the mycelium of $F$. oxysporum f. sp. lycopersici covers the whole plate. The inhibition percentage of $F$. oxysporum f. sp. lycopersici was calculated using the formula suggested by Sundar et al. (1995).

\subsection{Characterization of Bacteria}

Bacterial isolates were characterized through morphological and biochemical studies. Morphological characters like colony color, shape and surface textures were carefully studied and recorded using $24 \mathrm{hrs}$ of cultured bacterial isolates on NA medium.

\subsubsection{Gram's staining reaction}

Part of a young colony was heat fixed on a glass slide. It was flooded with Crystal violet solution for 1 minute and washed with running tap water, excess water was removed by air drying. Then it was flooded with Iodine solution (Lugol's Iodine) for 1 minute, washed with tap water and excess water was removed by air drying. After that it was decolorized with $95 \%$ Ethanol for 30 seconds, again washed with tap water and air dried. Then it was counterstained with $0.5 \%$ Safranine for 10 seconds and washed briefly under tap water, excess water was removed by air drying. Finally it was examined under microscope at $100 \mathrm{X}$ magnification.

\subsubsection{Biochemical characters}

For potassium hydroxide test, a loop-full of bacteria from a well grown colony was mixed with a drop of $3 \%$ aqueous $\mathrm{KOH}$ on a glass slide. A sterilized needle was raised a few centimeters from the glass slide and repeated strokes to have strands of viscid materials as described by Suslow et al. (1982). For Starch hydrolysis test, a nutrient agar plate containing $0.2 \%$ soluble starch was inoculated with the bacterium isolate to be tested, incubated for at least 48 hours, flooded with Lugol's iodine solution and observed. For catalase test, bacterial isolates were taken on a slide on which 
one drop of $3 \% \mathrm{H}_{2} \mathrm{O}_{2}$ (Hydrogen Peroxide) was added and observed. For oxidase test, a portion of the test organism was picked up on the wet oxidase disk containing tetramethyl-pphenylene-diamine dihydrochloride and color changed was obsrerved. For pecteolytic test, potato tubers were disinfected with $99 \%$ ethanol, cut into slices of about 7-8 $\mathrm{mm}$ thick and placed on moistened sterile filter paper in sterile petri-dish. Bacterial cell suspension was pipetted into a depression cut in the potato slices. One potato slice pipetted with sterile water was treated as control. Development of rot on the slices was examined 24-48 h after incubation at $25^{\circ} \mathrm{C}$. For citrate utilization test, a portion of the test organism was streaked into Simmon's citrate agar slants. Following incubation at $30^{\circ} \mathrm{C}$ for 24 hours color change was observed. For gelatin liquefaction test, one loop-full bacterial culture was stub inoculated into the media and incubated at $30^{\circ} \mathrm{C}$ for 24 hours. Gelatin liquefied microorganisms is detected by the formation of liquid culture in the presence of $4^{\circ} \mathrm{C}$ refrigerator. Hypersensitivity test of the isolated bacteria was done in tobacco plant as described by Wick (2006), where aqueous suspensions of the isolated bacteria at $10^{8} \mathrm{cfu} / \mathrm{ml}$ were injected into the intercellular space of the lower leaves.

\subsection{Efficacy of seed treatment with microbial antagonists}

For seed treatment with bacterial antagonist, bacterial cultures were scraped out and $10^{8}$ $\mathrm{cfu} / \mathrm{ml}$ suspensions were made in sterile distilled water in a beaker for each treatment. 400 seeds for each beaker were dipped in those beakers for four hours. For seed treatment with $T$. harzianum, spore suspension was made by scraping the 10-15 days old culture substrate with the help of blender @ one petriplate in 250 $\mathrm{ml}$ water to adjust the concentration $10^{7}$ conidia/ml solution. Collected tomato seeds were dipped in the spore suspension of $T$. harzianum for $1 \mathrm{hr}$. Four hundred seeds were surface sterilized with Chlorax @ 3\% and washed in distilled water served as control.
The study comprised of six treatments viz. $T_{1}=$ Seed treatment with Bacterial Isolate 1 (Iso-1), $\mathrm{T}_{2}=$ Seed treatment with Bacterial Isolate 2 (Iso2), $\mathrm{T}_{3}=$ Seed treatment with Bacterial Isolate 3 (Iso-3), $\mathrm{T}_{4}=$ Seed treatment with Bacterial Isolate 4 (Iso-4), $\mathrm{T}_{5}=$ Seed treatment with Trichoderma harzianum and $\mathrm{T}_{6}=$ Control (Untreated).

Prevalence of $F$. oxysporum in treated and untreated seeds was determined by blotter method (ISTA, 1996). Twenty five seeds were placed on three layers of moist blotting paper (Whatman No. 1) in each glass petri-dish. The petri-dishes were incubated at $25 \pm 1^{\circ} \mathrm{C}$ under $12 / 12$ hrs light and darkness cycle for 7 days. Each seed was observed in order to record the presence of fungus 7 days after incubation based on growth habit. The results were presented as percent incidence and germination of the seeds were also recorded.

Data collected during experimental period were tabulated and analyzed following statistical package MSTAT-C. Treatment means were compared with Duncan's Multiple Range Test (DMRT) (Gomez and Gomez, 1984).

\section{Results and Discussion}

In blotter test it was found that the seeds were infected by Fusarium oxysporum f. sp. lycopersici (11.25\%), Aspergillus flavus (12\%) and Curvularia sp. (5.25\%), respectively. White, fluffy mycelial colony of Fusarium oxysporum f. sp. lycopersici was isolated and purified from infected tomato seeds in PDA plate (Fig. 1). Similar types of colony were found by Begum (2007) and Altinok (2005).

Altogether 20 bacterial isolates were collected from soil samples using dilution plate technique and purified on NA medium. Of them, only four (Iso-1, Iso-2, Iso-3 and Iso-4) were recorded as antagonistic and were found to inhibit the growth of $F$. oxysporum f. sp. lycopersici in dual culture. The highest $(34.83 \%)$ growth of $F$. oxysporum $\mathrm{f}$. sp. lycopersici was inhibited by Iso-1 which was followed by Iso-4 (31.41\%), Iso-3 (29.96\%) and Iso-2 $(28.39 \%)$ as shown in Table 1 and Fig. 2. 
Among all the microbial antagonists studied the highest $(75.75 \%)$ inhibition of $F$. oxysporum $\mathrm{f}$. sp. lycopersici was observed in case of Trichoderma harzianum (Table 1 and Fig. 2). Sundar et al. (1995) and Deshmukh and Raut
(1992) reported that Trichoderma harzianum grew over the colonies of Fusarium oxysporum. Chabbi and Matrod (2002) achieved 77\% growth inhibition of Fusarium oxysporum with Trichoderma harzianum.
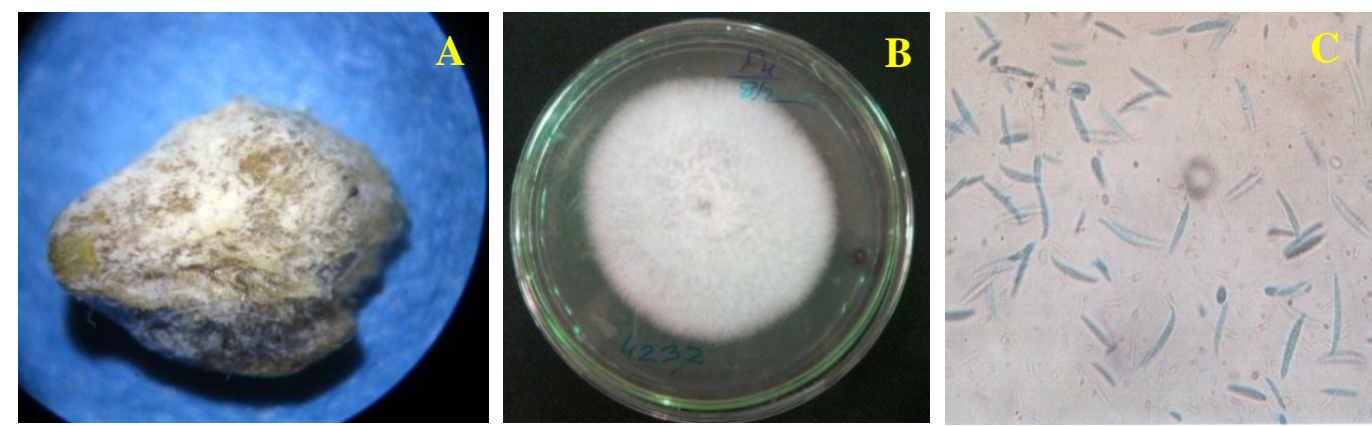

Fig. 1. A. Fusarium oxysporum f. sp. lycopersici on tomato seed under stereo microscope (50x)

B. Pure culture of Fusarium oxysporum f. sp. lycopersici on PDA

C. Conidia of Fusarium oxysporum $\mathrm{f}$. sp. lycopersici under compound microscope (40x)

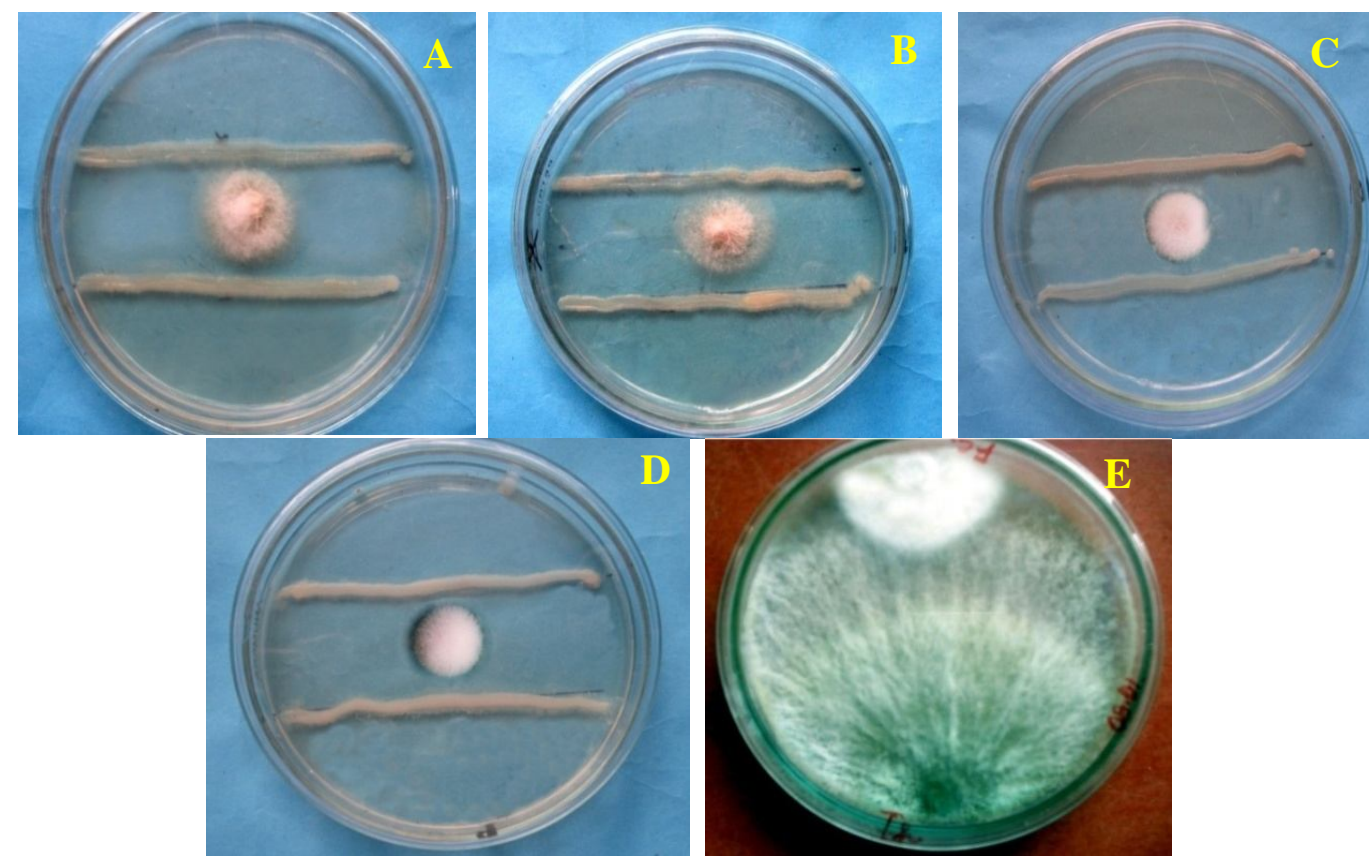

Fig. 2. Dual culture of Fusarium oxysporum f. sp. lycopersici with different rhizosphere microorganisms; A. Bacterial Iso-1, B. Bacterial Iso-2, C. Bacterial Iso-3, D. Bacterial Iso-4 and E. Trichoderma harzianum 
Table 1. Anti-fungal activity of antagonists studied against Fusarium oxysporum f. sp. lycopersici in dual culture method

\begin{tabular}{lc}
\hline Name of Antagonists & $\%$ Inhibition \\
\hline Iso-1 & $34.83 \mathrm{~b}$ \\
Iso-2 & $28.39 \mathrm{~d}$ \\
Iso-3 & $29.96 \mathrm{~cd}$ \\
Iso-4 & $31.41 \mathrm{c}$ \\
Trichoderma harzianum & $75.75 \mathrm{a}$ \\
LSD $_{(0.05)}$ & 2.944 \\
CV\% & 3.68 \\
\hline
\end{tabular}

Data having common letter ( $\mathrm{s})$ do not differ significantly $(\mathrm{p} \leq 0.05)$ by DMRT.

\subsection{Characterization of Bacteria}

Bacterial isolate Iso-1 showed creamy white, but other three showed slight yellow colored colony on NA medium after $24 \mathrm{hrs}$ of incubation. All of them had dome shaped, raised colony.

In Gram's staining, all antagonistic bacteria showed negative reaction and all the bacteria produced pink color, straight and curved rod with no particular arrangement (Table 2). All the bacterial isolates showed strands of viscid materials in repeated strokes in $\mathrm{KOH}$ solubility test. All the bacterial isolates except Iso-4 made clear zone after giving Lugol's iodine in agar plate containing $0.2 \%$ soluble starch. All the isolates formed bubble while mixing with $3 \%$ $\mathrm{H}_{2} \mathrm{O}_{2}$. Iso-2 formed dark purple color
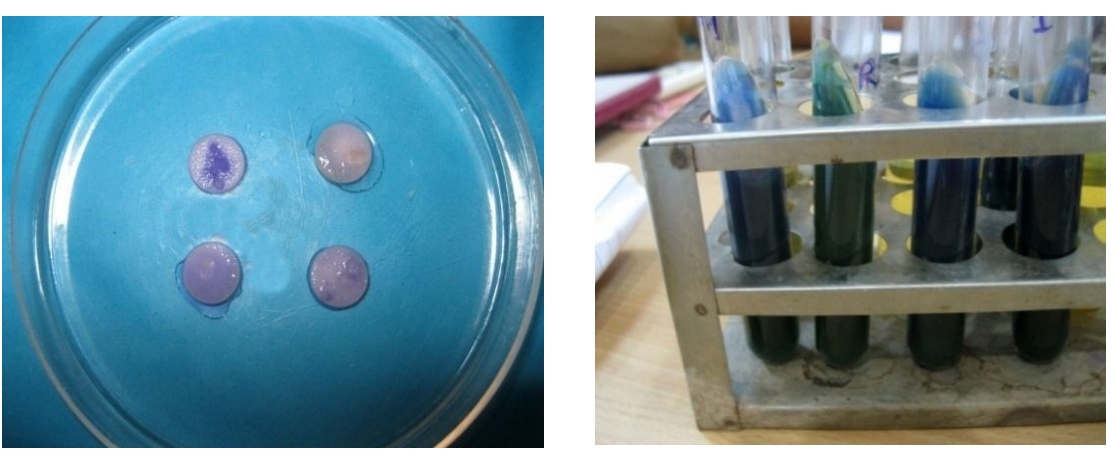

Fig. 3. A. Oxidase test and B. Citrate utilization test for different bacterial isolates

immediately while Iso-3 and Iso-4 produced after 20 seconds of picking the bacteria on to the oxidase disk and Iso-1 give negative result (Fig. 3 A). All bacterial isolates were unable to produce rot in potato slice. All the three isolates except Iso-1 changed Simmon's citrate agar slants color from green to bromothymol blue (Fig. $3 \mathrm{~A}$ ). All the isolates formed liquid culture in $4^{\circ} \mathrm{C}$ refrigeration. The bacterial isolates obtained from soil were not positive in hypersensitivity reaction on tobacco plants. Kreig (1923) and Schaad et al. (2001) reported that all the above characteristics are similar with the characteristics of different species of Pseudomonas. Thus, the isolates may be reports were given by Hossain (2006) and Wick (2006). different species of Pseudomonas. Similar 
Table 2. Biochemical characteristics of used antagonistic bacteria

\begin{tabular}{|lcccc|}
\hline Tests & \multicolumn{4}{c|}{ Reaction of the antagonistic bacteria } \\
\cline { 2 - 5 } & Iso-1 & Iso-2 & Iso-3 & Iso-4 \\
\hline Gram's staining reaction & - & - & - & - \\
KOH solubility Test & + & + & + & + \\
Starch Hydolysis & + & + & + & - \\
Catalase Test & + & + & + & + \\
Oxidase Test & - & ++ & + & + \\
Pecteolytic Test & - & - & - & - \\
Citrate Utilization Test & - & + & + & + \\
Gelatin liquefaction test & + & + & - & - \\
Tobacco Hypersensitivity Test & - & - & - & \\
\hline
\end{tabular}

$++=$ Strongly positive, $+=$ Positive, - =Negative
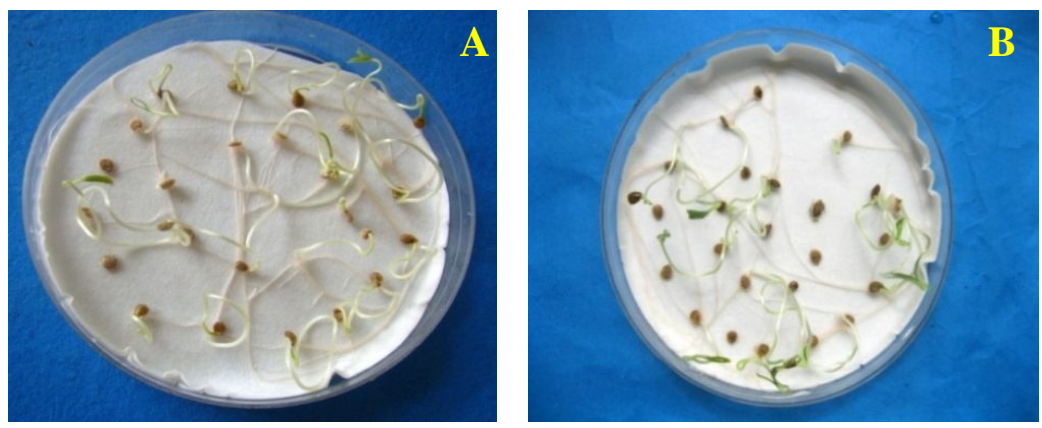

Fig. 4. Efficacy of seed treatment with selected microbial antagonists on incidence of Fusarium oxysporum f. sp. lycopersici; A. Tomato seeds treated with antagonistic bacteria and B. Untreated control

Table 3. Effect of different microbial antagonists on germination and incidence of seed borne fungi of BARI tomato-2 seed

\begin{tabular}{lllll}
\hline \multirow{2}{*}{$\begin{array}{l}\text { Name of } \\
\text { antagonists }\end{array}$} & Germination (\%) & \multicolumn{3}{c}{ Incidence of seed borne fungi (\%) } \\
\cline { 3 - 5 } & & $1.250 \mathrm{c}$ & $0.583 \mathrm{c}$ & Aspergillus spp. \\
$\mathrm{T}_{1}$ & $91.67 \mathrm{a}$ & $4.250 \mathrm{~b}$ & $3.500 \mathrm{bc}$ & $2.250 \mathrm{~b}$ \\
$\mathrm{~T}_{2}$ & $86.00 \mathrm{~b}$ & $4.167 \mathrm{~b}$ & $3.500 \mathrm{bc}$ & $0.333 \mathrm{c}$ \\
$\mathrm{T}_{3}$ & $85.53 \mathrm{~b}$ & $11.00 \mathrm{a}$ & $3.917 \mathrm{~b}$ & $2.333 \mathrm{~b}$ \\
$\mathrm{~T}_{4}$ & $86.67 \mathrm{~b}$ & $1.750 \mathrm{c}$ & $0.583 \mathrm{c}$ & $2.333 \mathrm{~b}$ \\
$\mathrm{~T}_{5}$ & $85.00 \mathrm{~b}$ & $12.00 \mathrm{a}$ & $11.25 \mathrm{a}$ & $5.250 \mathrm{a}$ \\
$\mathrm{T}_{6}($ Control) & $81.00 \mathrm{c}$ & 1.197 & 0.8931 & 0.3203 \\
$\mathrm{LSD}_{(0.05)}$ & 1.814 & 9.01 & 9.49 & 8.32 \\
$\mathrm{CV}_{0}$ & 1.16 & &
\end{tabular}

Means within the same column with a common letter (s) are not significantly different $(\mathrm{p} \leq 0.05)$ by DMRT. $\left[\mathrm{T}_{1}=\right.$ Seed treatment with Bacterial Isolate 1 (Iso-1), $\mathrm{T}_{2}=$ Seed treatment with Bacterial Isolate 2 (Iso-2), $\mathrm{T}_{3}=$ Seed treatment with Bacterial Isolate 3 (Iso-3), $\mathrm{T}_{4}=$ Seed treatment with Bacterial Isolate 4 (Iso-4), $\mathrm{T}_{5}=$ Seed treatment with Trichoderma harzianum and $\mathrm{T}_{6}=$ Control (Untreated).] 


\section{Conclusions}

The present study revealed that among all the microbial antagonists, Trichoderma harzianum was highly effective and among the bacterial isolates, Iso-1 was highly effective against $F$. oxysporum f. sp. lycopersici. Different biochemical tests revealed that the bacterial isolates may be different species of Pseudomonas. Therefore, Trichoderma harzianum and bacterial isolate, Iso-1 could be used as biocontrol agents against $F$. oxysporum $\mathrm{f}$. sp. lycopersici.

\section{References}

Altinok, H. H. 2005. First report of fusarium wilt of eggplant caused by Fusarium oxysporum f. sp. melongenae in Turkey. Plant Pathology, 54: 4.

Ashrafuzzaman, M. H. 1976. Laboratory manual of Plant Pathology. $1^{\text {st }}$ ed. Jaman Manjil, Iqbal Nagar, Khulna, Bangladesh, 97 p.

Azadeh, B. F., Sariah, M. and Wong, M. Y. 2010. Characterization of Burkholderia cepacia genom over I as a potential biocontrol agent of Ganoderma boninense in oil palm. African Journal of Biotechnology, 9(24): 3542-3548.

BBS. 2011. Agricultural Year Book of Bangladesh, Bangladesh Bureau of Statistics, Ministry of Planning, Govt. of Bangladesh, $43 \mathrm{p}$.

Begum, H. A. 2007. Studies on the integrated management for tomato wilt complex. Ph.D. Thesis, Department of Plant Pathology, Bangladesh Agricultural University, Mymensingh, $324 \mathrm{p}$.

Chaabi, S. A. and Matrod, L. 2002. Laboratory study to evaluate efficacy of different Trichoderma spp. isolates on some soilborne pathogenic fungi. Directorate of Agriculture Science Research, Douma, P. O. Box 113, Damascus, Syria. Arab Journal of Plant Protection, 20(2): 7783.
Cook, I. and Baker, R. 1983. The controlled experiment in the scientific method with special emphasis on biological control. Phytopathology, 74: 1019-1021.

Deshmukh, P. P. and Raut, J. G. 1992. Antagonism by Trichoderma sp. on five plant pathogenic fungi. New Agriculturist, 3 (2): 127-130.

Gomez, K. A. and Gomez, A. A. 1984. Duncan's Multiple Range Test. Statistical Procedure for Agril. Res. $2^{\text {nd }}$ ed. A Wiley Inter-Science Publication, Johan and Sons, New York, 202-215 pp.

Goszczynska, T. and Serfontein, J. J. 1998. Milk Tween Agar, a semiselective medium for isolation and differentiation of Pseudomonas syringae pv. syringae, Pseudomonas syringae pv. phaseolicola and Xanthomonas axonopodis pv. phaseoli. Journal of Microbiological Methods, 32(1): 65-72.

Hossain, M. A. 2006. Isolation and analysis of plasmid profile from Ralstonia solanacearum and Pseudomonas spp. and its reaction to antibiotics. MS Thesis, Dept. of Plant Pathology, Bangladesh Agricultural University, Mymensing, Bangladesh, 24-47 pp.

ISTA. 1996. International Rules for Seed Testing. International Seed Testing Association. Seed Science and Technology, 24:39-42.

Kirankumar, R., Jagadeesh, K. S., Krishnaraj, P. U. and Patil, M. S. 2008. Enhanced growth promotion of tomato and nutrient uptake by plant growth promoting rhizobacterial isolates in presence of tobacco mosaic virus pathogen. Karnataka Journal of Agricultural Science, 21(2): 309-311.

Kreig, N. R. 1923. Bergey's Manual of Systematic Bacteriology. Lippincot Williams and Wilkins. 351 West Camden St. Baltimore, USA, 140-170 pp. 
Merriman, P. and Russell, K. 1990. Screening Strategies for Biological Control of Soilborne Plant Pathogens. Edited by D. Hornby, Published by C. A. B. International, 427-435 pp.

Ogzonen, T. N., Lemanceau, P. and Alabouvette, C. 2001. Biocontrol of fusarium diseases by fluorescent Pseudomonas and nonpathogenic Fusarium. Crop Protection, 10: 279-286.

Schaad, N. W., Jones, J. B. and Chun, W. 2001. Laboratory guide for identification of Plant Pathogenic Bacteria. APS Press. The American Pathol. Society. St. Paul, Minnesota, USA, 84-98 pp.

Snyder, W. C. and Hansen, H. N. 1940. The species concept in Fusarium. American Journal of Botany, 27:64-67.
Sundar, A. R., Das, N. D. and Krishnaveni, D. 1995. In vitro antagonism of Trichoderma sp. against two fungal pathogens of castor. Indian Journal of Plant Protection, 23: 152-155.

Suslow, T. V., Schroth, M. N., and Isaka, M. 1982. Application of a rapid method for Gram differentiation of plant pathogenic and saprophytic bacteria without staining. Phytopathology, 72:917-918.

Weller, D., Raaijmakers, J., Gardener, B. B. and Thomashow, L. S. 2002. Microbial population responsible for specific soil suppressiveness to plant pathogens. Annual Review of Phytopathology, 40: 309-348.

Wick, R. L. 2006. Diagnostic Plant Pathology. Bangladesh Agricultural University, Mymensingh, 52-55 pp. 